\title{
Major and trace element geochemistry of Icelandic apatite: A case study at Torfajökull Volcano
}

\author{
TL CARLEY $^{1 *}$, L CONNORS $^{2}$, IMT REIN $^{1}$, ECV RUGER $^{1}$, \\ J GROSS $^{3}$, P BURGER ${ }^{3}$ \\ ${ }^{1}$ Lafayette College, Geology \& Envi. Geosciences, Easton, \\ USA, carleyt@lafayette.edu (*presenting author) \\ ${ }^{2}$ University of Oregon, Earth Sci., Eugene, USA, \\ lconnors@uoregon.edu \\ ${ }^{3}$ Rutgers University, Earth \& Planetary Sci., New Brunswick, \\ USA, jgross@eps.rutgers.edu
}

The potential contributions of apatite to investigations of magmatic and volcanic processes in Iceland are profound due to its unique ability to incorporate rare earth (REE), volatile ( $\mathrm{F}, \mathrm{Cl}, \mathrm{S})$, and redox-sensitive ( $\mathrm{S}, \mathrm{Mn}, \mathrm{Fe}$ ) elements. Despite its ubiquity as an accessory mineral, studies of Icelandic apatite are exceedingly recent and rare (Connors et al., in press and Bergpórsdóttir, 2018). Here, we aim to establish a baseline for the trace element and volatile compositions of Icelandic apatite using perspectives from active volcanic systems (Askja, Hekla, Krafla, and Torfajökull) and modern river systems (Miðá; Markarfljót; Jökulsá í Loní, and Lagarfljót). Against this contextualizing background, we use apatite to explore the geochemical evolution of Torfajökull.

Apatites are found as individual phenocrysts $(>100 \mu \mathrm{m})$ and as inclusions $(<10 \mu \mathrm{m})$ in plagioclase and zircon. Preliminary EMPA results suggest that Icelandic apatite are fluorapatite with low but variable $\mathrm{Cl}(\sim 0.05$ to $0.5 \mathrm{wt} \%)$ and total LREE $\left(\mathrm{La}_{2} \mathrm{O}_{3}+\mathrm{Ce}_{2} \mathrm{O}_{3}+\mathrm{Nd}_{2} \mathrm{O}_{3}: \sim 0.1\right.$ to $\sim 0.6 \mathrm{wt} \%$; cf. Torfajökull). The variable compatibility of $\mathrm{S}^{2-}$ vs $\mathrm{S}^{6+}$ in apatite (e.g., Parat et al. 2005 and Konecke et al. 2017) leads to wide-ranging S concentrations ( $<$ LOD to $\sim 1000 \mu \mathrm{g} / \mathrm{g}$ ).

We use five eruptions to represent Torfajökull's uniquely complicated magmatic history (384 ka - 1477 AD; higher Si peralkaline to lower Si metaluminous). Apatites from the oldest, coolest, peralkaline eruptions have exceptionally high LREE ( $\sim 5$ to $19 \mathrm{wt} \%$ total oxides); LREE in apatite from younger, warmer, metaluminous eruptions are lower ( 0.5 to 3 $\mathrm{wt} \%$ total oxides), as is more typical of other Icelandic apatite. Volatile contents also change through time, especially $\mathrm{Cl}$, which increases from $<$ LOD to $0.4 \mathrm{wt} \%$. S concentrations are low in apatites from the oldest and youngest units $(<\mathrm{LOD}$ to $100 \mu \mathrm{g} / \mathrm{g} \mathrm{S}$ ), as is expected in reduced environments. $\mathrm{S}$ concentrations in apatites from a $67 \mathrm{ka}$ eruption indicate a change in the $\mathrm{S}$ speciation of the melt $(\mathrm{n}=10$ : $<$ LOD to $<80$ $\mu \mathrm{g} / \mathrm{g} \mathrm{S}$, reduced; $\mathrm{n}=46: 80$ to $570 \mu \mathrm{g} / \mathrm{g} \mathrm{S}$, oxidized). This change is perhaps due to degassing and separation of an Srich volatile phase preceding or during apatite crystallization. 